\title{
Detection of Infectious Bronchitis Virus from Chicken Manifesting Respiratory Signs by Reverse Transcriptase Polymerase Chain Reaction
}

\author{
Niranjana S. Rajalakshmi ${ }^{1}$, Surya Sankar ${ }^{1 *}$, Anu Bosewell ${ }^{1}$, U. Rashi ${ }^{1}$, M. Mini ${ }^{1}$, \\ Binu K. Mani ${ }^{2}$ and I.S. Sajitha ${ }^{3}$
}

${ }^{1}$ Department of Veterinary Microbiology, ${ }^{3}$ Department of Veterinary Pathology, College of Veterinary and Animal Sciences, Mannuthy, Thrissur, Kerala, India

${ }^{2}$ Department of Veterinary Microbiology, College of Veterinary and Animal Sciences, Pookode, Wayanad, Kerala, India

*Corresponding author

\section{A B S T R A C T}

\begin{tabular}{|l|}
\hline Ke y w or d s \\
Infectious \\
bronchitis, RT - \\
PCR, Respiratory \\
pathogens \\
\hline Article Info \\
\hline Accepted: \\
22 July 2019 \\
Available Online: \\
10 August 2019 \\
\hline
\end{tabular}

The Indian poultry industry in spite of exhibiting excellent performance in poultry production and rearing is being put to several challenges in various fronts, particularly in the form of production losses due to several diseases. Considering the reports on the occurrence of avian respiratory diseases suspected for infectious bronchitis (IB) from different parts of Kerala, in the present study, a reverse transcriptase polymerase chain reaction (RT - PCR) was employed for rapid detection of infectious bronchitis virus. Tissue samples from ailing birds of different age groups manifesting respiratory signs which were brought to the Department of Veterinary Microbiology, College of Veterinary and Animal Sciences, Mannuthy during the period from June 2018 to June 2019 for disease investigation were subjected to ribonucleic acid extraction, complementary cDNA synthesis and subsequently RT - PCR. Among 87 samples, 37 were positive for IB.

\section{Introduction}

Poultry sector is one of the fastest growing sectors in animal husbandry. In rural as well as urban households, backyard desi chickens play an important role in uplifting the livelihood. Yet, in the present scenario, the incidence of infectious diseases such as infectious bronchitis (IB) keeps increasing, thus impeding the growth of poultry sector in many aspects.
Infectious bronchitis, caused by the infectious bronchitis virus (IBV) belonging to the family Coronaviridae, is a positive sense, single stranded, enveloped, RNA virus of about 27.6 $\mathrm{kb}$ in size. The virus has a diameter of about $120 \mathrm{~nm}$ and has large $(20 \mathrm{~nm})$ club-shaped surface projections made up of heavily glycosylated spike glycoprotein S (Cavanagh, 2005). Apart from spike protein, the other structural proteins include membrane (M), envelope $(\mathrm{E})$ and nucleocapsid $(\mathrm{N})$ proteins 
(Ignjatovic and Sapats, 2000). The disease is manifested in three different forms namely respiratory, reproductive and renal forms.

In this article, we report the detection of IBV from clinical cases of IB in chicken which were brought to the Department of Veterinary Microbiology, College of Veterinary and Animal Sciences, Mannuthy, during a period of 13 months for disease investigation.

\section{Materials and Methods}

\section{Collection of tissue samples}

Tissue samples from 87 ailing chicken of different age groups which were brought to the Department of Veterinary Microbiology, College of Veterinary and Animal Sciences, Mannuthy with respiratory signs during the period from June 2018 to June 2019 were utilised in the study. The birds were sacrificed and tissue samples such as liver, spleen, lungs, air sacs, kidneys and trachea were collected in individual RNase free vials. The tissue samples were homogenised thoroughly.

\section{RNA extraction}

Viral RNA was extracted from the homogenised tissue samples using TRIzol method of RNA extraction (Ahmad et al., 2007). The extracted RNA was stored at $-70^{\circ} \mathrm{C}$ for subsequent conversion to complementary DNA (cDNA). The purity and concentration of RNA was checked.

\section{cDNA synthesis}

First strand of cDNA was synthesised using Bio-rad cDNA synthesis kit (Bio-rad, USA). The reactions were set up in $0.2 \mathrm{~mL}$ PCR tubes as shown in table 1. Master mix was prepared excluding template RNA sample and nuclease free water was added individually to each reaction tube. The contents of the tube were mixed gently and spun briefly. The reaction mix was set up initially at $25^{\circ} \mathrm{C}$ for five minutes for priming, followed by $46^{\circ} \mathrm{C}$ for 20 minutes for reverse transcription and reverse transcription inactivation at $95^{\circ} \mathrm{C}$ for one minute. After synthesis, cDNA was stored at $-70^{\circ} \mathrm{C}$ until further use.

\section{Reverse Transcriptase Polymerase Chain Reaction (RT - PCR)}

The synthesised cDNA was subjected to RT PCR for the detection of IB. Complementary DNA synthesised from commercial vaccine served as positive control. Negative control was made up with nuclease free water. Working solutions of the primers were prepared at the concentration of $10 \mathrm{p} M / \mu \mathrm{L}$. The details of primers and their sequences are mentioned in table 2. The PCR mix and thermal cycling conditions are given in tables 3 and 4 respectively.

\section{Submarine agarose gel electrophoresis}

Amplified PCR products were resolved in one per cent agarose gel in $1 \mathrm{X}$ TBE buffer. Five microlitre of PCR product was loaded into the wells. A 100 base pair DNA ladder (SRL) was also run alongside the samples to ascertain the size of the amplified products.

\section{Results and Discussion}

\section{Post mortem examination}

In majority of the cases, congestion in lungs, air sacculitis, caseous exudates in trachea and enlarged kidney were observed. The post mortem lesions are shown in Fig.1.

\section{RNA extraction}

Optical densities of the extracted RNA samples at 260/280 $\mathrm{nm}$ and 260/230 nm were $2.02 \pm 0.17$ and $2.13 \pm 0.15$, respectively. When subjected to sphectrophotometry, a 
concentration yield of more than $50 \mathrm{ng} / \mu \mathrm{L}$ was observed in all the samples which indicated a good purity.

\section{cDNA synthesis}

The cDNA synthesised using iScript cDNA synthesis kit (Bio-rad, USA) was subjected to sphectrophotometry and possessed a concentration yield of more than $50 \mathrm{ng} / \mu \mathrm{L}$ which indicated good purity.

RT - PCR

On RT - PCR, out of total 87 samples, 37 (42.5 per cent) were positive for IBV with amplicon size of $143 \mathrm{bp}$. The agarose gel electrophoresis of RT-PCR for IBV targeting 5' UTR is depicted in Fig. 2.

Table.1 Composition of reaction mix for first strand cDNA synthesis

\begin{tabular}{|l|l|l|}
\hline Sl. No. & Item & Volume $(\boldsymbol{\mu L})$ \\
\hline $\mathbf{1 .}$ & Template RNA & 7.5 \\
\hline 2. & 5X reaction buffer & 4 \\
\hline 3. & Reverse transcriptase & 1 \\
\hline 4. & Nuclease free water & 7.5 \\
\hline & Total & 20 \\
\hline
\end{tabular}

Table.2 Primers and their sequences

\begin{tabular}{|l|l|l|}
\hline Sl. No. & Primer name & Primer sequence (5'-3') \\
\hline $\mathbf{1 .}$ & IBV UP & GCTTTTGAGCCTAGCGTT \\
\hline $\mathbf{2 .}$ & IBV DOWN & GCCATGTTGTCACTGTCTATT \\
\hline
\end{tabular}

Table.3 Polymerase chain reaction mix optimized for the amplification of IBV

\begin{tabular}{|l|l|l|}
\hline Sl. No. & Constituents & Volume $(\boldsymbol{\mu L})$ \\
\hline 1. & Template cDNA & 3 \\
\hline 2. & Forward primer $(10 \mathrm{p} M / \mu \mathrm{L})$ & 1 \\
\hline 3. & Reverse primer $(10 \mathrm{p} M / \mu \mathrm{L})$ & 1 \\
\hline 4. & Emerald Amp GT PCR master mix & 6.25 \\
\hline $\mathbf{5 .}$ & Nuclease free water & 1.25 \\
\hline & Total & 12.5 \\
\hline
\end{tabular}


Table.4 Thermal cycling conditions for the amplification of IBV

\begin{tabular}{|l|l|l|l|}
\hline \multicolumn{2}{|l|}{ Steps } & Temperature & Time \\
\hline Initial denaturation & $94^{\circ} \mathrm{C}$ & $5 \mathrm{~min}$. \\
\hline \multirow{3}{*}{35 cycles } & Denaturation & $94^{\circ} \mathrm{C}$ & $45 \mathrm{sec}$. \\
\cline { 2 - 4 } & Annealing & $58^{\circ} \mathrm{C}$ & $1 \mathrm{~min}$. \\
\cline { 2 - 4 } & Extension & $72^{\circ} \mathrm{C}$ & $1 \mathrm{~min}$. \\
\hline \multirow{2}{*}{ Final extension } & $72^{\circ} \mathrm{C}$ & $10 \mathrm{~min}$. \\
\hline \multicolumn{2}{|c|}{ Hold } & $4^{\circ} \mathrm{C}$ & $\infty \mathrm{min}$ \\
\hline
\end{tabular}

Figure.1 Post mortem lesions (1. Air sacculitis; 2. Lung congestion)

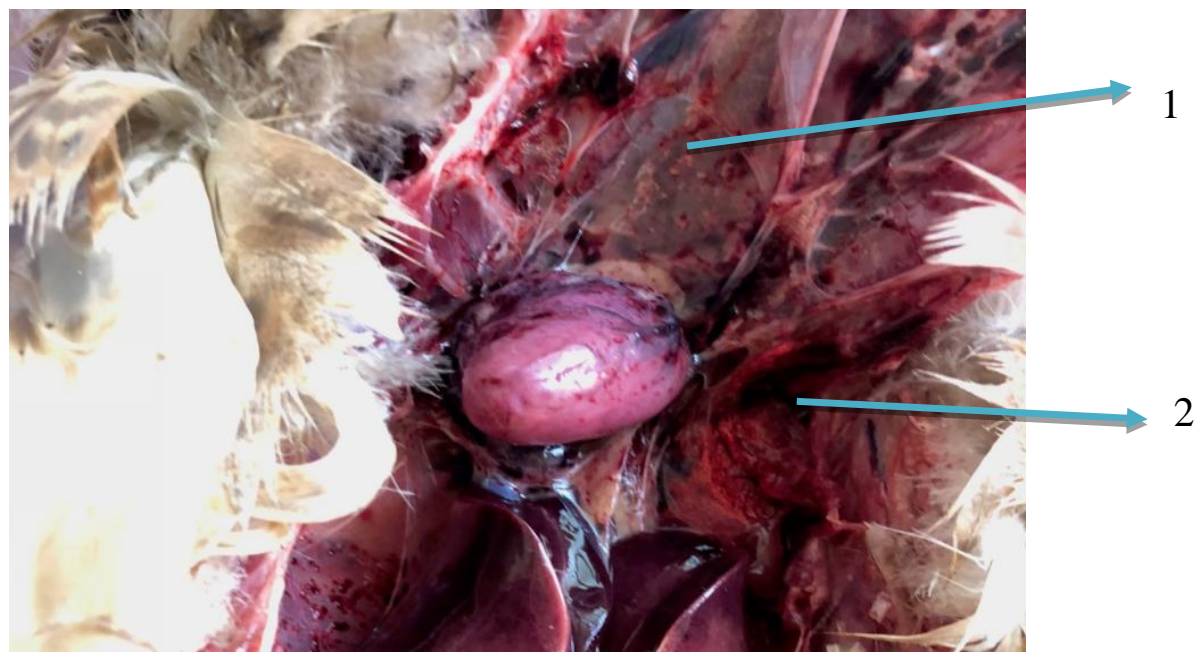

Figure.2 Agarose gel electrophoresis of PCR amplified products of IBV (Representation)

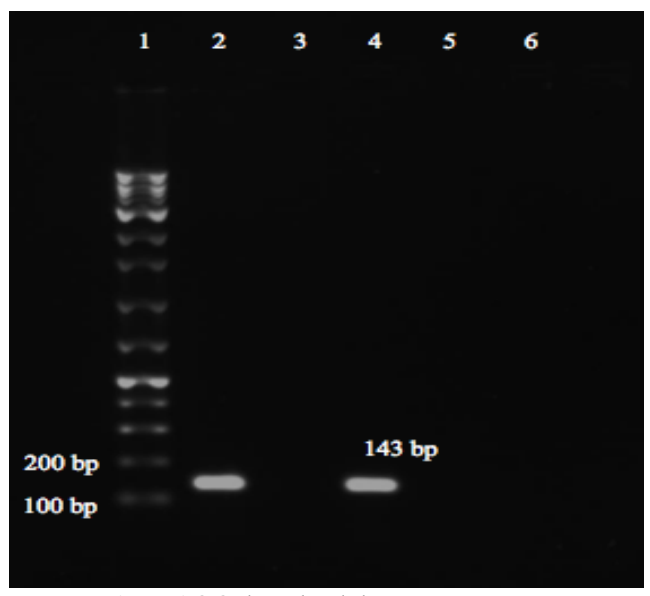

Lane $1-100$ bp ladder

Lane 2 - Positive control (143 bp)

Lane 3 - Negative control

Lane 4- Positive sample (143 bp)

Lane 5- Negative sample 
Infectious bronchitis is an OIE listed disease. Though mortality is not the primary concern regarding IB, it causes a pronounced economic loss to the poultry industry by deterioration in egg quality due to irreparable damage to the oviduct which results in misshapen eggs, thin albumen, etc. The genome of IBV encodes four structural proteins namely the nucleocapsid $(\mathrm{N})$, membrane glycoprotein (M), spike glycoprotein(S) and the envelope (E) protein. The spike glycoprotein after post-translational cleavage is further subdivided into $\mathrm{S} 1$ and $\mathrm{S} 2$ (Haqshenas et al., 2005). The IBV genome also has an untranslated region (UTR) which is highly conserved among various strains. Hence, for initial screening of the disease, detection of UTR can yield promising results (Andreasen et al., 1991).

Before the advent of PCR, diagnosis of IB was based upon various serological tests such as Complement fixation test, Enzyme linked immuno-sorbent assay, virus neutralisation test, immunoperoxidase test and agar gel precipitation test, etc. Virus isolation in embryonated chicken eggs is a confirmatory method for diagnosis. But it is laborious and time - consuming. Molecular detection methods like PCR, offers rapid and sensitive detection of the virus, especially during screening of large number of samples.

In the present study, tissue samples from 87 birds in different regions of Thrissur district manifesting respiratory signs were utilised for screening of IB. An RT - PCR targeting the 5' UTR of IBV was carried out, of which, 37 samples were positive for IB (42.5 per cent). High positivity for IB may be attributed to the fact that vaccination against IB is not being practiced in the state of Kerala. As far as Kerala is concerned, unpublished reports are available regarding the high prevalence of IB. The continuous and rapid emergence of various strains of viral agents with increased virulence poses a serious threat to the poultry industry (Dhama et al., 2014) which occurs in the form of mortality, reduced production, decreased feed conversion and loss of market value. Nucleotide sequencing and phylogenetic analysis are required to identify the prevalent strains so as to develop suitable vaccination protocol for effective control and prevention of disease in the state.

\section{Acknowledgment}

The authors are thankful to the Dean, College of Veterinary and Animal Sciences, Mannuthy for providing the facilities required for conducting this research.

\section{References}

Ahmad, Z., Naeem, K. and Hameed, A. 2007. Detection and seroprevalence of infectious bronchitis virus strains in commercial poultry in Pakistan. Poultry Science 86: 1329-1335.

Andreasen Jr, J.R., Jackwood, M.W. and Hilt, D.A. 1991. Polymerase chain reaction amplification of the genome of infectious bronchitis virus. Avian diseases Pp. 216-220.

Cavanagh, D. 2005. Coronaviridae: a review of coronaviruses and toroviruses. In: Coronaviruses with Special Emphasis on First Insights Concerning SARS. Birkhäuser Basel, Pp. 1-54.

Dhama, K., Karthik, K., Chakraborty, S., Tiwari, R., Kapoor, S., Kumar, A. and Thomas, P. 2014. Loop-mediated isothermal amplification of DNA (LAMP): a new diagnostic tool lights the world of diagnosis of animal and human pathogens: a review. Pakistan Journal of Biological Sciences 17(2): 151-166.

Haqshenas, G., Assasi, K. and Akrami, H. 2005. Isolation and molecular characterization of infectious bronchitis 
virus (IBV) Shiraz3 isolate by RT-PCR and restriction enzyme analysis. Iranian Journal of Veterinary Research 6(2): 994.

Ignjatovic, J. and Sapats, S. 2000. Avian infectious bronchitis virus. Revue Scientifique et Technique-Office International des Epizooties 19(2): 493501.

\section{How to cite this article:}

Niranjana S. Rajalakshmi, Surya Sankar, Anu Bosewell, U. Rashi, M. Mini, Binu K. Mani and Sajitha, I.S. 2019. Detection of Infectious Bronchitis Virus from Chicken Manifesting Respiratory Signs by Reverse Transcriptase Polymerase Chain Reaction. Int.J.Curr.Microbiol.App.Sci. 8(08): 3026-3031. doi: https://doi.org/10.20546/ijcmas.2019.808.350 